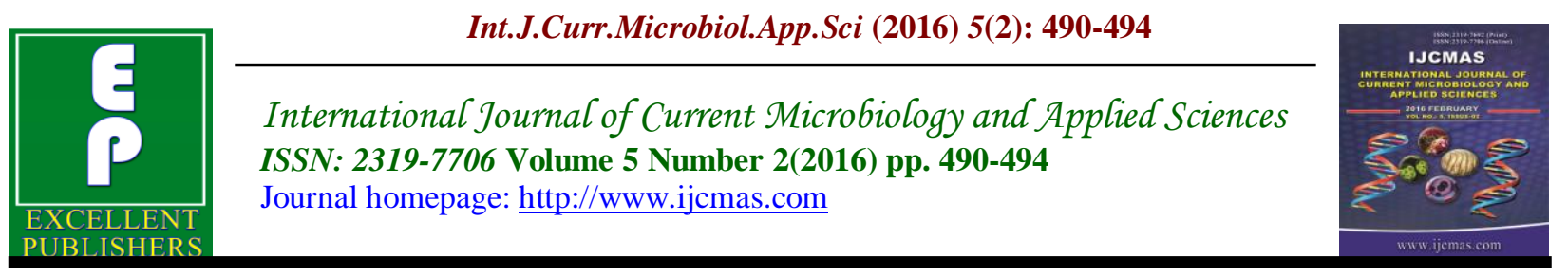

Original Research Article

doi: http://dx.doi.org/10.20546/ijcmas.2016.502.055

\title{
An Assessment of Protozoan Assemblage in Kottaipattinam Seasonal estuary, Pudukkottai District, Tamil Nadu
}

\author{
R. Saraswathi and P. Sumithra* \\ Department of Microbiology, Srimad Andavan Arts \& Science College, \\ Tiruchirappalli - 620 005, Tamil Nadu, India \\ *Corresponding author
}

\begin{abstract}
A B S T R A C T
Keywords

Protozoan,

estuary,

Season.

Article Info

Accepted:

25 January 2016

Available Online:

10, February 2016

As protozoans form an important link in the food web and are also used as indicators, the present study was aimed at assessing the protozoan assemblage in Kottaipattinam seasonal estuary, Pudukkottai District, Tamil Nadu during different seasons. A total of 14 species could be isolated. The rainy season recorded maximum diversity (13 sp.) followed by pre-summer (12 sp.), summer (10 sp.) and post-summer (9 sp.). The presence of species belonging to the genus Difflugia, Euplotes and Tachysoma suggests the system is polluted.

\section{Introduction}

A particular community of organisms may be useful as an environmental indicator due to many reasons. Some may have sensitivity to low levels of anthropogenic contaminants while some may tolerate in hardy and extreme conditions and some may react quickly to a change in the environment. Hence they become an unique biological tool to understand the ecological status of an aquatic habitat (Radhakrishnan and Jayaprakas, 2015). Among the various organisms, the use of protozoans as bioindicators for pollution and environmental biomonitoring has been recognized by a number of workers (Kolkwitz and Marsson, 1908; Liebmann, 1962; Curds, 1973; Madoni and Ghetti,

1981; Ricci, 1995) as they occur in large numbers in a very limited sample while other organisms used as indicators (molluscs, polychaetes and bacteria) are logically difficult to collect and also expensive to analyse (Radhakrishnan and Jayaprakas, 2015). Further, eventhough protozoans are minute in size, they take on a wondrous form of variety and structure but are sometimes rated as least important even though they play an important role which can be termed as useful, harmful and some on the border. While some of the useful forms of protozoans constitute important links in food web, act as indicators of petroleum deposits and are natural enemies of harmful bacteria helping in soil fertility,
\end{abstract}


some are harmful as they cause dreaded diseases to many organisms including man besides interfering with nitrate production and thus inhibiting soil fertility (Radhakrishnan and Jayaprakas, 2015). It is in this context the present study was attempted to isolate the protozoans that are present in the Kottaipattinam seasonal estuary of Pudukkottai District in Tamil Nadu, India during the different seasons of the year.

\section{Materials and Methods}

The collection of the free living protozoan's was from Kottaipattinam seasonal estuary of Pudukkottai District, Tamil Nadu. The collection was done on a seasonal basis (Pre-summer / Summer / Post-summer / Rainy season) during 2015. The water samples were collected during the early morning hours using a $63 \mu \mathrm{m}$ mesh sized plankton net. Water samples were brought to the laboratory in wide mouthed plastic bottles, lids removed and were kept in open in a place where adequate light was available. Rice bran was given as feed for these protozoans. The samples were examined under the microscope from time to time. The free living ciliates were observed in both $10 \mathrm{x}$ and $40 \mathrm{x}$ magnification, photographs taken and identified using standard references (Liebmann, 1962; Bick, 1973; Curds, 1973; Small, 1973; Msdoni and Ghetti, 1981; Salanki, 1986; Ricci, 1995).

\section{Results and Discussion}

The protozoans that were recorded in the system during the various seasons are presented in Table-1. As evident from the Table, a total of 14 species belonging to eight families were recorded. The family Centropyxidae and Difflugidae were represented by three species each, while the family Colepidae and Arcellidae were represented by two species each and the rest of the families (Nebelidae, Euglyphidae and Oxytrichidae) were represented by one species each. However, among the above species, only seven were perennial (Plagiopyxis decliris, Difflugia corona, D. binucleata, Nebella collaris, Paramecium caudatum, Euplotes sp. and Tachysona sp.). While $D$. binucleata recorded its highest count during the rainy season, $D$. corona recorded its peak during the presummer season and $P$. caudatum, Euplotes sp. and Tachysoma sp. recorded their highest count during the summer season. However, $N$. collaris recorded its peak during the post summer season. Nevertheless, an overall comparison of the various perennial species reveals that the most dominant protozoan was $P$. caudatum in terms of count.

During the pre-summer season, a total of 12 species were recorded of which two species each belonged to Arcelledae, Centropyxidae, Difflugidae and Colepidae and one species each to Nebelidae, Euglyphtidae, Euplotidae and Oxytrichidae. Among the two species of Arcellidae, A. discoides dominated while in Centropyxidae, $C$. aculeata dominated and among Difflugidae, D. corona dominated in terms of number. However, among Colepidae, $P$. caudatum dominated. An overall comparison of the various species that occurred during this season revealed that $P$. caudatum dominated in terms of number.

In the summer season, a total of 10 species were recorded of which two species each belonged to Centropyxidae and Difflugidae while the remaining were represented by a single species belonging to Arcellidae, Nebelidae, Euglyptidae, Colepidae, Euplotidae and Oxytrichidae. Among the two species of Centropyxidae, $P$. decliris dominated and among Difflugidae $D$. 
corona dominated in terms of number. However, an overall comparison of the various species that occurred during this season reveals that $P$. caudatum was the most dominant species in terms of count.

Table.1 Seasonal Occurrence of Protozoan Population of Kottaipattinam Estuary (i/l)

\begin{tabular}{|c|c|c|c|c|c|}
\hline $\begin{array}{c}\text { S. } \\
\text { No. }\end{array}$ & Species & $\begin{array}{c}\text { Rainy } \\
\text { (Oct-Dec, } \\
\text { 2014) }\end{array}$ & $\begin{array}{c}\text { Pre-summer } \\
\text { (Jan-Mar, } \\
\text { 2015) }\end{array}$ & $\begin{array}{c}\text { Summer } \\
\text { (Apr-Jun, } \\
\text { 2015) }\end{array}$ & $\begin{array}{c}\text { Post-summer } \\
\text { (Jul-Sep, } \\
\text { 2015) }\end{array}$ \\
\hline \multicolumn{6}{|c|}{ I. Arcelledae } \\
\hline 1. & Arcella discoides & 40 & 30 & 20 & 0 \\
\hline 2. & Arcella hemisphaerica & 30 & 20 & 0 & 0 \\
\hline \multicolumn{6}{|c|}{ II. Centropyxidae } \\
\hline 3. & Plagiopyxis declivis & 20 & 30 & 60 & 70 \\
\hline 4. & Lesqueresia spiralis & 40 & 0 & 30 & 50 \\
\hline 5. & Centropyxis aculeata & 20 & 70 & 0 & 0 \\
\hline \multicolumn{6}{|c|}{ IV. Difflugidae } \\
\hline 6. & Difflugia corona & 200 & 280 & 70 & 80 \\
\hline 7. & Difflugia binucleata & 60 & 40 & 30 & 20 \\
\hline 8. & Difflugia lobostoma & 30 & 0 & 0 & 0 \\
\hline \multicolumn{6}{|c|}{ V. Nebelidae } \\
\hline 9. & Nebela collaris & 20 & 10 & 20 & 40 \\
\hline \multicolumn{6}{|c|}{ VI. Euglophidae } \\
\hline 10. & Euglypha tuberculata & 0 & 30 & 40 & 60 \\
\hline \multicolumn{6}{|c|}{ VII. Colepidae } \\
\hline 11. & Coleps hirtus & 20 & 30 & 0 & 0 \\
\hline 12. & Paramecium caudatum & 260 & 260 & 340 & 280 \\
\hline \multicolumn{6}{|c|}{ VIII. Euplotidae } \\
\hline 13. & Euplotes sp. & 30 & 100 & 120 & 60 \\
\hline \multicolumn{6}{|c|}{ IX. Oxytrichidae } \\
\hline 14. & Tachysoma sp. & 20 & 120 & 140 & 70 \\
\hline
\end{tabular}

During the post-summer season, a total of nine species were recorded of which two species each belonged to Centropyxidae and Difflugidae and the remaining were represented by one species each belonging to the families Nebelidae, Euglyphtidae,
Colipidae, Euplotidae and Oxytrichidae. Among the two species of Centropyridae, $P$. decliris dominated while among Difflugidae, D. corona dominated. Nevertheless, a comparison of the various species that occurred during the season 
reveals that the most dominant species in terms of count was $P$. caudatum. Thus a comparison of the seasonal protozoan diversity reveals that the rainy season recorded the highest diversity followed by the pre-summer, summer and post-summer seasons.

A comparison of the protozoan diversity during the different seasons reveals that during the rainy season a total of 13 species were recorded. The only species to be absent during this seasonal was E. tuberculata. Among Arcellidae, the most dominant species in terms of number was $A$. discoides while among Centropyxidae, the dominant species was L. spiralis. However, among the three species of Difflugidae, the most dominant species in terms of number was $D$. corona and among Colepidae, the dominant species was $P$. caudatum. An overall comparison of the various species that occurred during this season reveals that the most dominant species was $P$. caudatum followed by $D$. corona in terms of number.

A perusal of literature reveals that a total of 1567 species of free living protozoans have been recorded from India, including the estuarine, marine and moss dwelling forms. The first report of free living protozoans from India was done by Cantor (1842) who reported the occurrence of six species of freshwater protozoa from West Bengal, while Mukherjee and Das (2000) reported the presence of five protozoans in Renuka wetland, Himachal Pradesh and Bindu (2010) while monitoring the protozoans in various districts of West Bengal reported species ranging from 11 (Darjling district) to 102 (Kolkatta district). Recently, Radhakrishnan and Jayaprakas (2015) while monitoring the free living protozoans in Kerala (Vembanad) reported a total of 19 species. Thus, the diversity of protozoans when compared to other systems is in line with the observations in general made by others even though it is on the lower side when compared to the diversity obtained by Bindu (2010) for Kolkatta district.

In the present study, species belonging to the genus Difflugia, Euplotes and Tachysoma were recorded. According to Radhakrishnan and Jayaprakas (2015) the presence of the above species are clear signs of pollution as these species are commonly used as pollution indicators. According to Dujardin (1841) Euglypha tuberculata noted in the present study is a species of wide tolerance and has the ability to thrive in diverse habitats. According to Radhakrishnan and Jayaprakas (2015) Cryptodiffugia oviformis prefers dry environments. Further, they also help in active decomposition process.

The present study recorded the presence of both rhizopods and ciliates. According to Chiverrell (2001) and Charman et al. (2004) the presence of rhizopods which usually have short generation time and wide distribution can be used as indicators for monitoring environmental change while Shakoori et al. (2004) suggested that ciliates are usually found in polluted waters containing $<10 \mu \mathrm{g} / \mathrm{ml}$ of toxic metal ions. Curds (1973) reported that they help to regulate bacterial population and BOD levels. Further, the presence of Euplotes sp. and Tachymonas sp. recorded in the present study can be used for bioremediation of industrial waste water as they possess heavy metal uptake properties as suggested by Radhakrishnan and Jayaprakas (2015).

\section{References}

Bick, H. (1973). Population dynamics of Protozoa associated with the decay of organic materials in freshwater. Amer. Zool., 13: 149-160. 
Bindu, L. (2010). Free-living protozoan diversity of West Bengal. J. Environ. and Sociobiol., 7: 195-196.

Cantor, T. (1842). General features of chusan, with remarks on the flora and fauna of that island. Annals and Magazine of Natural History, Series1. 9: $\quad$ 481-493.

Charman, D. J., Brown, A. D., Hendon, D. and Karofeld, E. (2004). Testing the relationship between Holocene peatland paleoclimate reconstructions and instrumental data at two European sites. J. Quatern Sci. Rev., 23: 137-143.

Chiverrell, R. C. A. (2001). Proxy record of late Holocene climate change from May Moss, North-east England. J. Quatern. Sci., 16: 9-29.

Curds, C. R. (1973). The role of Protozoa in the activated sludge process. Amer. Zool., 13: 161-169.

Dujardin, F. (1841). Histoirenaturelle des Zoophyrtes. Infusorienwelt, Suites a Buffon, Paris. p. 678.

Kolkwitz, R. and Marsson, M. (1908). Okologie der pflanzlichen saprobien. Ber Deut. Bot. Ges., 26: 505-519.

Liebmann, H. (1962). Hambuch der frishawasserund Abwasser. Biologie: Biology des Trinkwassers, Badiwassers, Fischwassers, Vofluters and Abwasser. Vol. 1, $2^{\text {nd }}$ edn., Munich, Olderburge.

Madoni, P. and Ghetti, F. (1981). The structure of ciliated protozoa communities in biological sewage treatment plants. Hydrobiologia, 83: 207-215.

Mukherjee, R. N. and Das, A. K. (2000). Fauna of Renuka wetland - Wetland Ecosystem Series 2. Zoological Survey of India, pp. 7-9.

Radhakrishnan, R. and Jayaprakas, V. (2015). Free living protozoans as bioindicators in Vembanad lake, Kerala, India: An important Ramsar site. Int. J. Fish. Aqua. Stud. 2: 192197.

Ricci, N. (1995). Protozoa: Bioindicators of environmental monitoring and pollution control. In: Pollution and Biomonitoring. Tata McGraw-Hill, New Delhi. pp. 240-269.

Salanki, J. (1986). Biological monitoring of the state of the environment: Bioindicators. An overview of the IUBS Programme on Bioindicators. IBUS-Monogr. Ser., Vol. I, IRL Press, London.

Shakoori, A. R., Rehman, A., Haq, R. U. (2004). Multiple metal resistance in the ciliate protozoan, Vorticella microstoma, isolated from industrial effluents and its potential in bioremediation of toxic wastes. Bull. Environ. Contam. Toxicol., 72: 10461051.

Small, E. B. (1973). A study of ciliate Protozoa from a small polluted stream in East Central Illinois. Amer. Zool., 13: $225-230$.

\section{How to cite this article:}

Saraswathi, R., and Sumithra, P. 2016. An Assessment of Protozoan Assemblage in Kottaipattinam Seasonal estuary, Pudukkottai District, Tamil Nadu. Int.J.Curr.Microbiol.App.Sci. 5(2): 490-494. doi: http://dx.doi.org/10.20546/ijcmas.2016.502.055 